\title{
Survey of Existing Farming System and Agroforestry Practices in the Lohardaga District, Jharkhand, India
}

\author{
Bijay Kumar Singh ${ }^{1 *}$, P. R. Oraon", Shashi Ranjan², \\ Abhay Kumar ${ }^{3}$ and Kanchan Kumar Suman ${ }^{4}$ \\ ${ }^{1}$ Department of Silviculture and Agroforestry, ${ }^{2}$ Department of Basic Science and Humanity, \\ ${ }^{3}$ Birsa Agricultural University, Ranchi, Jharkhand, India \\ ${ }^{4}$ Department of Forest Products and Utilization, Faculty of Forestry, India \\ *Corresponding author
}

\section{A B S T R A C T}

\section{Keywords}

Agroforestry, Agrisilvicultural, Agrohorticultural, Monthly Income, Land Holding

Article Info

Accepted:

18 August 2019

Available Online:

10 September 2019
Agroforestry has been recognized as one of the important systems for supporting the livelihoods of rural farmers. Maximum number of male population was $55.05 \%$ female population was $44.95 \%$ in survey area. Maximum age class 30-40 (48.75\%) followed by age class $40-50(23.75 \%)$, maximum $51.25 \%$ of respondents belong to medium size family followed by $35.00 \%$ in small size family. Maximum $65 \%$ of respondents were scheduled tribe followed by $28.75 \%$ in backward caste, maximum $32.50 \%$ of respondents were under Rs. 3001-5000 monthly income followed by $30.00 \%$, maximum $50.00 \%$ of respondents was 1-2 ha land holding followed by $37.50 \%$ in 2-4 ha. In Agrisilviculture system found tree crop like Artocarpus heterophyllus, Azadirachta indica, Dalbergia sissoo, Gmelina arborea, Leucaena leucocephala, Melia azedarech, Syzygium cumini, Tectona grandis and agriculture crop 1;ike Triticum aestivum, Brassica nigra Pisum sativum, Zea mays, Oryza sativa, Solamum tuberosum, Lycopersicon esculentum. In agrihorticulture system grow tree like Artocarpus heterophyllus, Litchi chinensis, Mangifera indica, Syzygium cumini and agriculture crop like Lycopersicon esculentum, Solanum melongena, Zingiber officinale, Capsicum annuum, Colocasia schott. Different agroforestry practices fulfilled the demand of rural households and extra income sources. However, only few households adopted high income based agroforestry activities. It should be extended to all households and need to be supported by government.

\section{Introduction}

Agroforestry is an age old practice followed by every rural household for supporting their local needs which also maintains the microclimate and aesthetic of the surrounds. Agroforestry focuses on the wide range of trees grown on farms and other rural areas. Among these are fertilizer trees for land regeneration, soil health and food security; fruit trees for nutrition; fodder trees for livestock; timber and energy trees for shelter and fuel wood; medicinal trees to cure diseases and trees for minor products viz. 
gums, resins, or latex products, Many of these trees are multipurpose, providing a range of benefits. Scientific agroforestry emphasized for increase in the productivity from unit area by incorporation of tree components in intensive agricultural practices like agrisilviculture, agrihorticulture, Silvopastural, agrisilvihorticulture, etc. these practices by and large applied to large farm holding but small land holders are interested in home garden type model which is most primitive and followed in all around the tropics (Leakey 1996). According Forest Survey of India (2013), the forest cover in the country is $6,96,898 \mathrm{~km}^{2}$, constituting $21.23 \%$ of its total geographical area. Out of this, dense forest constitutes $2.54 \%$ and open forest $8.99 \%$. The forest cover is the hilly district is only $38.34 \%$ compared with the desired $66 \%$ area. India is estimated to have between 14,224 million and 24,602 million trees outside forests spread over an equivalent area of 17 million ha (Singh and Pandey, 2011). The national agriculture policy (2000) emphasized the role of agroforestry for efficient nutrient cycling, nitrogen fixation, and organic matter addition and for improving drainage and underlining the need for diversification by promoting integrated and holistic development of rainfed area on watershed basis through involvement community tegument biomass production through agroforestry and farm forestry. Agroforestry system involves basically three processes of growth, management and interactions. Growth relates to trees, crops, pastures and animals; while management refers to the effective and efficient use of climate, water, soil, plants and animals as the case may be. Interactions on the other hand refer to the tree-crop, tree-pasture, and treeanimal associations. Furthermore, when the growth of trees is combined with cultivation and sometimes with animals, it provides an essential part of an agricultural system which facilitates both productive and protective functions (Young, 1989).

\section{Materials and Methods}

Lohardaga District is situated in the southwest portion of the Jharkhand state. It is lies at $23^{\circ}$ 21' 0" North, 84 48' 0" East longitude. The general climate of the region is sub-tropical and annual average temperature is $23{ }^{0} \mathrm{C}$ the highest temperature goes to $42{ }^{\circ} \mathrm{C}$ in summer and lowest of $8{ }^{\circ} \mathrm{C}$ in winter. The site receives annual rainfall of 1000 to $1600 \mathrm{~mm}$. The mean relative humidity is about $76.28 \%$ in the area. The monsoon breaks out in the middle of June and last till mid October. Multi stage random sampling was adopted to select the households. Bhandra block was selected randomly in the first stage. Four panchayats were selected randomly for the study. A list of villages was prepared for each selected panchayat. From each village, twenty households were selected using simple random sampling. Thus, a total of 80 households were selected for the purpose of this study. Each village was visited before administering the questionnaires. Interviews were conducted during the evenings (near dinner time) and early mornings, for farmers who were available only during these times. The questionnaire was then finalized on the basis of validity, suggestions, corrections and comment of the research supervisor and experts. A few modifications and reduction in the number of questions were done taking cognizance of time constraints of the interview.

\section{Results and Discussion}

\section{Socioeconomic profile}

The Socioeconomic study of the area is shown in Table 1.The table indicated that the maximum number of male population was $55.05 \%$ female population was $44.95 \%$ in survey area. Maximum age class 30-40 
$(48.75 \%)$ followed by age class $40-50$ (23.75\%), maximum $51.25 \%$ of respondents belong to medium size family followed by $35.00 \%$ in small size family. The reading the size of family reveals that majority of small and medium families have been observed indication a clear cut dominance of small and medium families among respondents confirming the report of Bisaliah (1995), Ranjan et al., (2017), Thakur et al., (2018) and Kumar et al., (2018). Medium size of family is indicated that the tribals have a tendency to live in nuclear family as also reported by Sachidananda (1979) and Srivastava (1982). Kutcha type of house was found maximum $(66.25 \%)$ followed by Mixed house type (27.5\%), maximum $33.75 \%$ of respondents was intermediate followed by $26.25 \%$ in high school. The literacy status of people residing in the research area are literate or having elementary level education. In Bangladesh $44 \%$ of all house hold heads are literate and also mention that high literacy level, strongly correlated with use of more services it also indicate and eliminates of empowerment and awareness Rasid (2002). Maximum 65\% of respondents were scheduled tribe followed by $28.75 \%$ in backward caste, maximum $32.50 \%$ of respondents was under Rs. 3001-5000 monthly income followed by $30.00 \%$, maximum $50.00 \%$ of respondents was $1-2$ ha land holding followed by $37.50 \%$ in $2-4$ ha. Dwivedi et al., (2007) the marginal farmers had an average land holding of 0.71 ha, the small farmer had a land holding of 3.14 ha while the medium to large farmer holding size was 3.46 ha thus the overall holding size of the sample farmers in Aligarh district was 1.52 ha. Chauhan and Ingle (1988) studied the role of farm forestry in Akola district of Vidharba region (Maharastra) and reported that majority of farmers have small landholding, none of the small and marginal farmers had adopted farm or agroforestry (Marwar et al.,1993). In Ranchi district the average land holding of the farmers ranges between 2.79 to 3.75 acres in all surveyed village (Jha and Ranjan, 1993). Saxena (1996) reported in North West India $52 \%$ of the large farmers (those owning more than 2.5 ha.) 175 of the small farmers (owning between 0.5 and 2.5 ha) and $5 \%$ of tiny farmers (with less than $0.5 \mathrm{ha}$ ) planted trees on their farm under agroforestry concept. Singh and Dagar (1996) have presented survey of agroforestry system undertaking in the Mussorie hills near Dehradun (U.P.). About $80 \%$ of landholdings were $<1$ ha, $15 \%$ were 1 - 2.5 ha and $5 \%$ were $2.5-10$ ha. The systems identified were agrisilviculture, agrihorticultural, agrisilvihorticultural, silvipastoral and homesteads. This finding supports the present fining become percentage of small landholding are more than large landholding. Maximum $68.75 \%$ of respondents were their own source and minimum was $31.25 \%$ were purchased from markets. Similarly, Dwivedi et al., (2007) the majority of farmers $(50.6 \%)$ farm trees where a prime source of fuel wood and hence they protected the same in Western Uttar Pradesh and in the Bastar region of Chhattisgarh fulfilling the all basic requirement from agroforestry practices like food, fodder and fuel etc. and also getting extra benefit or income (Hemrom and Nema, 2015).

Maximum $96.25 \%$ of mode of cattle feeding was both stall feeding and grazing and minimum was $3.75 \%$ were only grazing, maximum $60 \%$ of respondents were mixed crop followed by inter crop $22.5 \%$. According to Hemrom and Nema (2015) agroforestry can be seen in all part of Bastar region of Chhattisgarh.

The farmers are planting trees inside and outside their farm and practices many agroforestry practices like boundary plantation, headge row and intercropping etc. Similar result find in Zaman et al., 2010, Ranjan et al., 2017, Kumar et al., 2018, Kumari et al., 2018 and Thakur et al., 2018. 
Table.1 Socioeconomic profile

\begin{tabular}{|c|c|c|}
\hline Component & $\mathrm{F}$ & $\%$ \\
\hline \multicolumn{3}{|c|}{ Population } \\
\hline Male & 311 & 55.05 \\
\hline Femal & 254 & 44.95 \\
\hline \multicolumn{3}{|c|}{ Age class } \\
\hline $20-30$ & 11 & 13.75 \\
\hline $30-40$ & 39 & 48.75 \\
\hline $40-50$ & 19 & 23.75 \\
\hline $50-60$ & 11 & 13.75 \\
\hline \multicolumn{3}{|c|}{ Size of Family } \\
\hline Small & 28 & 35.00 \\
\hline Medium & 41 & 51.25 \\
\hline Large & 11 & 13.75 \\
\hline \multicolumn{3}{|c|}{ House type } \\
\hline Kutcha & 53 & 66.25 \\
\hline Mixed & 22 & 27.5 \\
\hline Pucca & 5 & 6.25 \\
\hline \multicolumn{3}{|c|}{ Education attainment } \\
\hline Illiterate & 8 & 10 \\
\hline Elementary & 15 & 18.75 \\
\hline High school & 21 & 26.25 \\
\hline Intermediate & 27 & 33.75 \\
\hline College & 9 & 11.25 \\
\hline \multicolumn{3}{|c|}{ Social class } \\
\hline Scheduled tribe & 52 & 65.00 \\
\hline Backward caste & 23 & 28.75 \\
\hline General & 5 & 6.25 \\
\hline \multicolumn{3}{|c|}{ Monthly income } \\
\hline $1001-3000$ & 24 & 30.00 \\
\hline $3001-5000$ & 26 & 32.50 \\
\hline $5001-7000$ & 20 & 25.00 \\
\hline $7001-9000$ & 10 & 12.50 \\
\hline \multicolumn{3}{|c|}{ Land size } \\
\hline Below 1 ha & 5 & 6.25 \\
\hline 1 to $2 \mathrm{ha}$ & 40 & 50 \\
\hline 2 to 4 ha & 30 & 37.5 \\
\hline 4 to $10 \mathrm{ha}$ & 5 & 6.25 \\
\hline \multicolumn{3}{|c|}{ Source of fodder and fuel } \\
\hline Own source & 55 & 68.75 \\
\hline Purchase source & 25 & 31.25 \\
\hline \multicolumn{3}{|c|}{ Mode of feeding cattle } \\
\hline
\end{tabular}




\begin{tabular}{|c|c|c|}
\hline Stall feeding & 0 & 0.00 \\
\hline Grazing only & 3 & 3.75 \\
\hline Both & 77 & 96.25 \\
\hline & Cropping pattern & \\
\hline Sole crop & 14 & 17.5 \\
\hline Mixed crop & 48 & 60 \\
\hline inter crop & 18 & 22.5 \\
\hline
\end{tabular}

Table.2 Socioeconomic profile

\begin{tabular}{|l|c|c|}
\hline \multicolumn{1}{|c|}{ Component } & F (n= 80) & Occupation \\
\hline Agriculture & $80 \#$ & 100 \\
\hline Labour & $32 \#$ & 40 \\
\hline Private job & $8 \#$ & 10 \\
\hline Construction work & $12 \#$ & 15 \\
\hline Other if any & $16 \#$ & 20 \\
\hline \multicolumn{2}{|c|}{ Land use practics } \\
\hline Agriculture & $80 \#$ & 100 \\
\hline Horticulture & $19 \#$ & 23.75 \\
\hline Agroforestry & $37 \#$ & 46.25 \\
\hline Fallow & $53 \#$ & 66.25 \\
\hline Other purpose & $34 \#$ & 42.5 \\
\hline Multiple answer \# & & \\
\hline
\end{tabular}

Table.3 Soil properties of different land use practices

\begin{tabular}{|l|l|c|c|c|c|c|}
\hline S.N. & \multicolumn{1}{|c|}{ Treatment } & $\mathbf{p H}$ & $\mathbf{O ~ C}(\mathbf{\%})$ & Nitrogen & Phosphorus & Potash \\
\hline $\mathbf{1 .}$ & Agrisilvicultural & 6.20 & 0.423 & 255.27 & 17.24 & 243.22 \\
\hline $\mathbf{2 .}$ & Agrihorticultural & 6.10 & 0.386 & 236.09 & 14.79 & 238.70 \\
\hline $\mathbf{3 .}$ & Silvipasture & 6.13 & 0.304 & 216.03 & 15.78 & 223.02 \\
\hline $\mathbf{4 .}$ & Homegarden & 6.18 & 0.420 & 251.03 & 15.25 & 238.48 \\
\hline $\mathbf{5 .}$ & Sole tree & 6.10 & 0.332 & 209.54 & 15.93 & 204.02 \\
\hline $\mathbf{6 .}$ & Sole crop & 6.10 & 0.442 & 256.29 & 20.06 & 255.58 \\
\hline $\mathbf{7 .}$ & Barren land & 5.47 & 0.258 & 177.190 & 10.45 & 185.37 \\
\hline & SE m \pm & 0.058 & 0.011 & 5.046 & 0.036 & 4.780 \\
\hline & CD at 5\% & 0.172 & 0.034 & 15.107 & 1.078 & 14.313 \\
\hline & CV \% & 1.906 & 6.195 & 4.411 & 4.605 & 4.203 \\
\hline
\end{tabular}


Table.4 Tree and agriculture crop combination in Agroforestry System

\begin{tabular}{|c|c|c|}
\hline $\begin{array}{l}\text { Agroforestry } \\
\text { system }\end{array}$ & Tree species & Agricultural crop \\
\hline $\begin{array}{l}\text { Agrisilviculture } \\
\text { System }\end{array}$ & $\begin{array}{l}\text { Artocarpus heterophyllus, Azadirachta indica, } \\
\text { Dalbergia sissoo, Gmelina arborea, Leucaena } \\
\text { leucocephala, Melia azedarech, Syzygium } \\
\text { cumini, Tectona grandis }\end{array}$ & $\begin{array}{l}\text { Triticum aestivum, Brassica nigra Pisum } \\
\text { sativum, Zea mays, Oryza sativa, } \\
\text { Solamum tuberosum, Lycopersicon } \\
\text { esculentum }\end{array}$ \\
\hline $\begin{array}{l}\text { Agrihorticulture } \\
\text { System }\end{array}$ & $\begin{array}{l}\text { Artocarpus heterophyllus, Litchi chinensis, } \\
\text { Mangifera indica, Syzygium cumini }\end{array}$ & $\begin{array}{l}\text { Lycopersicon esculentum, Solanum } \\
\text { melongena, Zingiber officinale, } \\
\text { Capsicum annuum, Colocasia schott }\end{array}$ \\
\hline $\begin{array}{l}\text { Silvipasture } \\
\text { system }\end{array}$ & Dalbergia sissoo and Mangifera indica & Cynodon dactylon and Cyperus scariosus \\
\hline $\begin{array}{l}\text { Homegarden } \\
\text { system }\end{array}$ & $\begin{array}{l}\text { Artocarpus heterophyllus, Azadirachta indica, } \\
\text { Dalbergia sissoo, Gmelina arborea, Litchi } \\
\text { chinensis, Mangifera indica, Syzygium cumini } \\
\text { and Tectona grandis }\end{array}$ & $\begin{array}{l}\text { Solamumtu berosum, Allium cepa, } \\
\text { Solanum melongena, Capsicum annuum, } \\
\text { Zingiber officinale Colocasia schott, } \\
\text { Lycopersicon esculentum and Zea mays }\end{array}$ \\
\hline
\end{tabular}

The data has indicated in the Table 2 the respondents of all Bhandra were engaged in Agriculture (100\%). Besides agriculture, the respondents are engaged in labour (40\%), private job (10\%), constructions work (15\%) and other (20\%). As per Behr and Lee (2004) approximately $25 \%$ of these households in Periyar Tiger Reserve Kerala also engaged in off-farm activities. The number of working people engaged in business and government service profession was found very few. The study has indicated that in all the respondents of all Panchayats were engaged in agriculture $(100 \%)$. Besides agriculture, the respondents are engaged in horticulture $(23.75 \%)$, agroforestry (46.25\%), fallow land (66.25\%), and in other purpose (42.5\%). Almost similar observation had been reported by Rasid (2002) in Bangladesh indicated that involvement in agriculture in most household's are the primary occupation found in observation about $63 \%$ of household depend on one form of agriculture or another ranging from agriculture producing crops on their own land to selling labour for agriculture, $59 \%$ of occasionally poor household depend upon agriculture production on their own land, 23\% depend on a combination of production from their own land and sharecropping, while $44 \%$ of the always poor household work primarily as agriculture labourers in Bangladesh. Similar study has been carridied out by Saxena (1996) in North West India, where he has noticed $52 \%$ large farmar (more than $2.5 \mathrm{ha}$ ), $17 \%$ small farmers (between 0.5 - 2.5 ha) and tiny farmer (less than $0.5 \mathrm{ha}$ ) planted trees on their farm under agroforestry concept. Similar result finds in Zaman et al., 2010, Islam et al., 2012, Kumar et al., 2018 and Thakur et al., 2018.

\section{Soil properties of different land use practices}

The soil properties obtained from different land use practices in Bhandra block is presented in Table 3. The soil properties like $\mathrm{pH}$, organic contents (\%), nitrogen, phosphorus and potash were analyzed under different treatment i.e. in agrisilvicultural, agrihorticultural, sole tree, sole crop and barren land. Perusal of data has indicated that the highest $\mathrm{pH}$ was found in agrisilvicultural system i.e. 6.2 whereas minimum $\mathrm{pH}$ was found in barren land i.e. 5.47. The organic content $(\%)$, nitrogen, phosphorus and potash 
were found maximum in sole crop because of regular use of fertilizer in field whereas nitrogen and potash were found minimum in sole tree. The phosphorus was found minimum in agrihorticultural system whereas the organic content $(\%)$ was found minimum in barren land. Statistically organic content (\%), nitrogen, phosphorus and potash were found significant at 5\% among the treatments. Mishra et al., (1982) have reported soil physical properties $\mathrm{pH}$, nitrogen and organic carban after four year under silvipastoral system in calcaseous soil. Similarly, Sharma and Prasad (1980) found growing Sissoo trees proved to be beneficial in improving the site by increasing organic carban and nitrogen sustainability as compared to fallow land. Growing of Sissoo in association with acable crops has been shown to providing sustainability to the traditional acable for in dry region by Subramanyam et al., (1991). The beneficial effects of trees has been shown by authors such as Khonje (1989) has compared soil characterististics under agroforestry Leucaena leucocephala, Gmalina arborea, Eucalypyus camaldulensis and monocropping (Maize) and noticed improvement in $\mathrm{pH}$ or organic carban under tree environment. Similary, Rai et al., (2001) reported higher level of organic carban in silvipastoral system as compare to pasture alone.

\section{Tree and agriculture crop combination in Agroforestry System}

Tree and agriculture crop combination was indicated in table 4. In Agrisilviculture system found tree crop like Artocarpus heterophyllus, Azadirachta indica, Dalbergia sissoo, Gmelina arborea, Leucaena leucocephala, Melia azedarech, Syzygium cumini, Tectona grandis and agriculture crop 1;ike Triticum aestivum, Brassica nigra Pisum sativum, Zea mays, Oryza sativa, Solamum tuberosum, Lycopersicon esculentum. In agrihorticulture system they grow tree crop like Artocarpus heterophyllus, Litchi chinensis, Mangifera indica, Syzygium cumini and agriculture crop like Lycopersicon esculentum, Solanum melongena, Zingiber officinale, Capsicum annuum, Colocasia schott. In silvipasture system Dalbergia sissoo and Mangifera indica, and grasses Cynodon dactylon and Cyperus scariosus where as in homegarden system tree crop were found Artocarpus heterophyllus, Azadirachta indica, Dalbergia sissoo, Gmelina arborea, Litchi chinensis, Mangifera indica, Syzygium cumini and Tectona grandis and agricultural crop like Solamumtu berosum, Allium cepa, Solanum melongena, Capsicum annuum, Zingiber officinale Colocasia schott, Lycopersicon esculentum and Zea mays. Similar study found in Hemrom and Nema, 2015, Toppo et al., 2016, Lakra et al., 2017, Kumar et al., 2017, Singh and Oraon 2017 and Kumar et al., 2018.

Traditional agroforestry systems and practices associated with them plays an important role in securing the sustainable livelihood security of the rural people of Bhandra block. Most of the people are doing agriculture and labour work in the area. Approx 50\% household doing agroforestry in block. Maximum number of people having land holding size per household is 1-2 ha. They should provide scientific guidance to the farmers about suitable tree species grown on agricultural land with agricultural crops, their silvicultural operations and tree management practices along with free supply of seeds and seedlings and loan schemes for the promotion of agroforestry. Surveys are required to be conducted in Lohardaga district more awareness and training programme on scientific methods of agroforestry are required so as to increase income and employment generation at farm level. The Govt. should take proper initiative to supply credit and loan facilities to farmers and arrange training and workshop on cultivation and management of agroforestry. 


\section{References}

Bisaliah, S. (1995). Decision making on Farm Forestry: Role of Socio Economic and Institutional factors; FarmForestry in South Asia Ed. N.C. Saxena \& Vishwa Ballabh Saga Publication, pp. 219 244.

Chauhan P. S. and Ingle, P. O. (1988). Role of farm forestry in meeting the fuel wood requirement of the villages. Advances in Forestry Research in India, Vol. II 1988 ed. Ram Prakash. IBD.

Dwivedi P. R., Karemulla, K., Singh R., Rizvi, R.H. and Chauhan J. (2007). SocioEconomic Analysis of Agroforestry Systems in Western Uttar Pradesh. Indian Res. J. Ext. Edu. 7 (2\&3), May \& September.

FSI, (2013) Forest Survey of India, Ministry of Environment and Forest, Govt. of India. Dehradun.

Hemrom, A. and Nema, S. (2015). A study on traditional agroforestry practices existing at Bastar region of Chhattisgarh. International Journal of Multidisciplinary Research and Development, 2(3):56-64.

Islam, W. M., Islam, M.M. and Sadath N. M. (2012) Contributions of Agroforestry Practice Towards Reducing Poverty at Kedhabpur Upazila of Jessore District - A case study, J. Environ, Sci. \& Natural Resources, 5(2): 267-274

Jha, L. K. and Ranjan (1993). Impact of farm/agroforestry on village socioeconomic life (A case study), Agroforestry - Indian persective. Pp $277-300$.

Khonje, D.J. (1989). The tree potential of Leucaeua Leucocephala in the agroforestry system in Malawi. Trees for development in sub Saharan Africa. Proceeding of a Regional Seminar held by the International Foundation for science (IFS), ICRAF House, Nairobi,
Kenya Feb. 20-25, 143-149.

Kumar, A., Sah, R. B., Singh, B. K. and Oraon, P. R. (2017) Tree Species Preferences on Agroforestry Practices in Bishunpur Block of Gumla District, Jharkhand. Trends in Biosciences 10(40), 8508-8516

Kumar, A., Sah, R. B., Singh, B. K. and Oraon, P. R. (2018). Socioeconomic Analysis of Tribal Farmers in the Gumla District of Jharkhand from Existing Agroforestry Practices Int.J.Curr.Microbiol. App.Sci (2018) 7(6): 595-604

Kumari, N. Malik, M. S., Kumar, J. and Kumari J. (2018) Socioeconomic and Livelihood analysis in the Namkum Block of Ranchi District, Jharkhand from Agroforestry Practices, Multilogic in Science, VOL. VIII, issue special(C) pp: 238-241.

Lakra, T, S., Siddiqui, M.H., Chakraborty, A.K., Oraon, P.R. and Malik, M. S. (2018). Agroforestry Practices Feollowed in West Singhbhum District, Jharkhand. Trends in Biosciences, 11(4): pp 400 - 406

Leakey, R. R. B. (1996). Definition of agroforestry revisited. Agroforestry Today, 8(1): 5-7.

Marawar, S. S,, Ingle, O.P., Mukewar, M. A. and Deshmukh, G. R. (1993). Socioeconomic analysis of farm forestry in Vidhana of Maharastra State. Advance in forestry research in India. Vol - IX pp 219-232.

Mishra, S. M., Patil, B. D. and Pathak, P. S. (1982). Comparative differences in soil properties as a result of growing different grass legume and tree combinations, Indian J. Range Mgmt. 3 (1\& 2): 71-74.

National Forest Police (2000) Government of India, Ministry of Environment and Forest,. New Delhi.

Oraon. P. R., Yadav, M. S. and Siddiqui, M. 
H. (2005). Comparative performance of Agroforestry in Kumharia Village of Ranchi District. Indian Journal of Agroforestry. Vol. 7 No. 2: pp 19 -24.

Rai, P., Yadav, S. R., Solanki, R.K, Rao, R.G. and Singh, R. (2001). Growth and prouned biomass production of multipurpose tree species in silvipastoral on degraded lands in semi-arid region of Uttar Pradesh, India Forest Tree and Livelihood 11: 347-364.

Ranjan, R., Shekhar, S. and Singh, C.V. (2017) Diagnostic Survey of Existing Farming System and Agro Forestry Practices in the Koderma District of Jharkhand, India,Int.J.Curr.Microbiol.App.Sci6(9) : pp: 1936-1943.

Rasid, D. A. (2002). The finding of the Northwest Rural Livelihoods Monitoring Project, Care Bangladesh. pp. 59 - 67.

Sachchidananda (1979). The changing Munda concept Publication Co. New Delhi.

Saxena, N. C. (1996). Farm Forestry in North West India - A case study. Indian Forester, 122 (7):560-569.

Singh, V. P. and Dagar, J.C. (1996) Agroforestry system for Mussoorie Hilles Western Himalayas in special Issue. Indian Forester, 122 (7): 610 614.

Singh, V.S. and Pandey, D.N. (2011) Multifunctional Agroforestry systems in India: Science based policy options.
RSPCB Occasional Paper No. 4/2011, Rajasthan State pollution Control Board.

Srivastava, R. M. (1982) Cattle in Culture and economy of Tribal Mundas of Bihar. $\mathrm{Ph}$. D. Thesis (Unpub.) Div. Dairy Extn., N.D.R.I., Karnal.

Subramanyam, M.V.R., Bheemaiah, G. and Lsmall, S. (1996). Compatibility of available crops intercropped Dalbergia sissoo For Sustainable rained agriculture. Indian Forester, 122 (7):646-650.

Thakur, P. K., Malik, M. S., Singh, B. K. and Oraon, P. R. (2018). Assessment of socioeconomic status of agroforestry farmers in Giridih District, Jharkhand, Journal of Pharmacognosy and Phytochemistry; SP1: 929-932

Toppo P., Raj A. and Jhariya M. K. (2016) Agroforestry systems practiced in Dhamtari district of Chhattisgarh, India, Journal of Applied and Natural Science 8 (4).

Young, A. (1997). The effectiveness of contour hedgerows for soil and water conservation. Agroforestry Forum, 8(4): 224-227.

Zaman, S. Siddiquee, U. S. and Katoh. M. (2010) Structure and Diversity of Homegarden Agroforestry in Thakurgaon District, Bangladesh The Open Forest Science Journal, 3, pp 3844.

\section{How to cite this article:}

Bijay Kumar Singh, P. R. Oraon, Shashi Ranjan, Abhay Kumar and Kanchan Kumar Suman. 2019. Survey of Existing Farming System and Agroforestry Practices in the Lohardaga District, Jharkhand, India. Int.J.Curr.Microbiol.App.Sci. 8(09): 1625-1633.

doi: https://doi.org/10.20546/ijcmas.2019.809.185 